\title{
Resource-Saving Cleaning Technologies for Power Plant Waste-Water Cooling Ponds
}

\author{
Lyudmila Zakonnova ${ }^{1,}{ }^{*}$, Igor Nikishkin ${ }^{2}$, and Alexandr Rostovzev ${ }^{3}$ \\ ${ }^{1}$ T.F. Gorbachev Kuzbass State Technical University, Belovo Branch, 652644 Ilyicha st. 32, Inskoy, \\ Kemerovo oblast, Russia \\ ${ }^{2}$ Belovo Fish Center Ltd., 652644 Technologichesky Dist., 3, Inskoy, Kemerovo oblast, Russia \\ ${ }^{3}$ FSUE "Gosrybcentr", Novosibirsk branch, 630091 Novosibirsk, 1 Pisareva st. Russia
}

\begin{abstract}
One of the frequently encountered problems of power plant small cooling ponds is rapid eutrophication and related intensified development of phytoplankton ("hyperflow") and overgrowing of ponds by higher aquatic vegetation. As a result of hyper-flowering, an enormous amount of detritus settles on the condenser tubes, reducing the efficiency of the power plant operation. The development of higher aquatic vegetation contributes to the appearing of the shoals. As a result the volume, area and other characteristics of the cooling ponds are getting changed. The article describes the environmental problems of small manmade ponds of power plants and coal mines in mining regions. Two approaches to the problem of eutrophication are considered: technological and ecological. The negative effects of herbicides application to aquatic organisms are experimentally proved. An ecological approach to solving the problem by fish-land reclamation method is shown.
\end{abstract}

\section{Introduction}

Today the correlation between different factors of sustainable development - socioeconomic and ecological development of old industrial regions is in focus of many Russian researches [1-4]. A special role in improving of ecological situation in mineral resources extracting areas is played by wastewater purification and water sources preservation [5-9]. Modern monitoring tools ensure the use of remote methods instead of expensive direct measurements, which allows more accurate and more dynamic predicting of aquatic ecosystems development, both of natural and anthropogenic origin [10-15]. At the same time, methods of direct monitoring and experimental approbation of their purification are still relevant to the study of ecological problems of small man-made water ponds of coal-mining and coal-processing enterprises.

We observe two approaches to the power and coal plants waste-water cooling ponds purifying problem solvation: technological and environmental. The technological approach does not take into account the interests of existing community of organisms; its supporters still believe that eutrophication of the pond is most expedient with the help of herbicides, in particular, $\mathrm{Cu}^{2+}$ salts. An ecological approach to this problem solvation takes into account

\footnotetext{
*Corresponding author: nir_belovo@mail.ru
} 
the fact that during the existence of the cooling pond, a co-society of organisms was formed in it, and the pond itself became a part of the ecosystem of the district and a recreation zone for the citizens.

\section{Materials and Methods}

Among the known measures to fight herbal forms, the most environmentally friendly and economically acceptable is the method for pond cleaning with the help of fish meliorators microphytophagous carp and macrophytophage white amur. Initially, this method was used for biological cleaning of irrigation systems in Central Asia, but recently it is getting increasingly used in Western Siberia, in particular, in the reservoirs of Belovskaya power plant and Berezovskaya-1 power plant, belonging to the Ob River basin.

With the undoubted advantage of such a method, it has weak points, for example, longterm consequences for aboriginal ichthyocenosis in connection with introduction of competing fish. Microphytophagous carp in the Ob River basin has few food competitors, so it will not reduce the productivity of native fish species. Macrophytophage white amur, with a lack of preferred plant species, extends the nutritional spectrum and becomes a benthophagus, undermining the fodder base of tuvod fish. Therefore, the introduction of white cupid into cooling ponds should be carried out taking into account the conditions of each specific pond.

We considered the situation that developed in the cooling pond of Belovskaya power plant (Belovskoe reservoir). Belovskaya power plant works on a circulating system of technical water supply. A water cooling pond is a reservoir formed by regulating the flow of the Inya River. The project area of the reservoir is 1300 hectares, at present it is 1430 hectares, the volume of water is $47.9 \times 10^{6} \mathrm{~m}^{3}$.

Water to cool the condensers of the power plant is taken from the dam of the pond and getting discharged along a diverting channel about $6 \mathrm{~km}$ long into the upper reach. The average flow of circulating water in the discharge channel is $35 \mathrm{~m}^{3} / \mathrm{sec}$ in summer.

A characteristic feature of the Belovskaya power plant is the constancy of the load. The operation of the power plant in a constant mode provides not only a constant flow of circulating water, but also the absence of sharp fluctuations in its temperature in the daily and weekly periods.

At the initial stage of the formation of the hydroecosystem, the cooling pond at the Belovskaya power plant had features of an oligotrophic type of pond with insignificant tendencies towards the mesotrophic state. At present some indicators (chlorophyll content "a", zoobenthos biomass, oxygen content in bottom water, transparency) have eutrophic values. The biomass of phytoplankton increased in 3.1 times, primary production increased in 2.6 times, chlorophyll a content - in 7.1 times, biomass of zooplankton - in 2.6, zoobenthos - in 3.9 times.

Studies of a number of scientists, including V.V. Kirillov et al. allowed to assess the level of production and destruction processes in the cooling pond of Belovskaya power plant, to estimaye the current state of zoobenthos and zooperifiton and higher aquatic vegetation of the pond and compare the obtained data with the results of other authors [16-21].

Thus, as a result of more than forty years of operation of the cooling pond of the Belovskaya power plant, the eutrophication of the reservoir occurred quite naturally under the existing conditions. The biomass of phyto- and zooplankton, higher aquatic vegetation significantly increased, and in this connection there was a danger that detritus, depositing on condenser tubes of power station, would reduce the degree of water cooling. In 1998-1999 years summer "flowering" of the reservoir was particularly high, therefore, since 2000, works have begun to clean the Belovo Reservoir. According to V.A. Smirnov and co- 
authors, the index of the species diversity of the Belovo Reservoir reaches 3.2-3.5 (with a maximum possible value of 6), the hydrobiocenosis is represented by 418 organisms, including 17 species of tuvodia and 7 introduced species of fish.

\section{Results and Discussion}

All the data given indicate that a mesotrophic-eutrophic ecosystem has developed in the Belovskaya power plant cooling pond. In this case, the use of herbicides can lead to the death of many species of hydrobionts and the degradation of the reservoir. Therefore, the fight against further eutrophication of the reservoir should be carried out by soft ecological methods, among which are the use of herbivorous fish - silver carp and white amur - to combat plankton and higher aquatic vegetation. In 2000, we developed the "Fish and Biological Substantiation for Additional Filling of the Belovskaya power plant cooling ponds with herbivorous fish", according to which fat carp had been produced in the reservoir.

Table 1. Fish-breeding indicators, which can be obtained in 4-8 years after stocking the cooling pond of the Belovskaya power plant with silver carp

\begin{tabular}{|c|c|c|c|c|c|c|}
\hline Timing & $\begin{array}{c}\text { Average } \\
\text { piece } \\
\text { weight, } \\
\text { kg }\end{array}$ & $\begin{array}{c}\text { Total } \\
\text { weight, } \\
\text { tons }\end{array}$ & $\begin{array}{c}\text { Survival } \\
\text { for the } \\
\text { period, } \\
\%\end{array}$ & $\begin{array}{c}\text { The } \\
\text { number of } \\
\text { individuals, } \\
\text { thousand } \\
\text { pieces }\end{array}$ & $\begin{array}{c}\text { The increase in the } \\
\text { ichthyomass for the } \\
\text { period, } \\
\text { tons }\end{array}$ & $\begin{array}{c}\text { Feed } \\
\text { Ratio }\end{array}$ \\
\hline $\begin{array}{c}4 \text { years } \\
\text { after } \\
\text { stocking }\end{array}$ & 0.15 & 5 & & 33370 & & $15-60$ \\
\hline $\begin{array}{c}8 \text { years } \\
\text { after } \\
\text { stocking }\end{array}$ & 4.0 & 80 & 60 & 20022 & & 75 \\
\hline
\end{tabular}

At the same time, with the undoubted advantages of ecological methods for controlling the overgrowing of water bodies, unauthorized use of herbicides can not be denied, such as copper sulfate, especially since such cases occurred in the late 1970s.

Therefore, in 2000, under the conditions of the Belovo Fisheries, an investigation was made of the possible consequences of the use of $\mathrm{Cu}^{2+}$ salts for the ichthyofauna of the Belovo Reservoir by the "fish test" method, whose tasks included the following: the detection of toxic and safe carp endothelial cells and larvae; the concentration of copper pentasulphate; determination of the effect of copper sulfate solutions of different concentrations on fertilization, embryogenesis and early postembryogenesis of; identification of the longterm consequences of the influence of $\mathrm{Cu} 2+$ ions for carp fry.

It is known that the most sensitive to the action of copper are embryos and larvae of fish [22-26]. In connection with this material, developing embryos, pre-larvae, larvae and carp fry were used in research (Cyprinus carpio, L). Young carp were obtained in the production conditions of the Belovo fish farm using standard technology. For the purity of the experiment, the descendants of one female fish were used in all variants.

The mother liquor of copper penta-sulphate $\left(\mathrm{CuSO}_{4} * 5 \mathrm{H}_{2} \mathrm{O}\right)$ was prepared in distilled water, working solutions of different concentrations were made using the technological water of the Belovskoye Reservoir, since it is known that the toxic effect of copper ions depends on a number of reasons: hardness, oxygen content, organic compounds, suspensions [13]. Solutions containing from 0.02 to $10 \mathrm{mg} \mathrm{CuSO}_{4} * 5 \mathrm{H}_{2} \mathrm{O} /$ liter were used (Tables 2,3$)$. 
Copper sulfate solutions of different concentrations were used to activate sperm and the process of eggs developing. To determine the effect on embryogenesis, fertilized caviar was placed in solutions of copper sulphate, for the activation of the sperm and the swelling of the eggs, ordinary technological water was used. In order to detect the effect of copper ions on pre-larvae, intact hatching embryos were taken and placed to stand in solutions of copper sulfate of various concentrations. To determine the long-term consequences of the action of copper ions on developing carp fry, all the larvae surviving in previous experiments were grown during the usual technology for fish farming.

The criteria for the quality of embryos and postembryons were survival, growth rate, and the presence of individuals with various malformations. Each experimental group consisted of 100 individuals.

As a result of the studies, it was found that the maximum toxic effect of copper ions on embryos is manifested when using solutions of copper sulfate directly during the fertilization of eggs, as when swelling solutions enter the eggs. Survival of embryos in a concentration solution of $0.08 \mathrm{mg} /$ liter was $25.6 \%$, in a solution with a concentration of $0.02 \mathrm{mg} /$ liter $-39.2 \%$, in control samples $-86.7 \%$.

When the eggs were incubated, which was fertilized with technological water, the survival of embryos was found to depend on the copper sulfate concentration in solutions (Table 2).

Table 2. Survival of carp embryos during incubation in solutions of copper sulfate of various concentrations

\begin{tabular}{|c|c|c|c|c|c|c|c|c|c|c|}
\hline $\begin{array}{c}\text { Concentration } \\
\text { CuSO } \\
\text { ma } * \mathbf{5 H}_{2} \mathbf{O}, \\
\text { mg/liter }\end{array}$ & $\mathbf{1 0}$ & $\mathbf{5}$ & $\mathbf{1}$ & $\mathbf{0 . 2}$ & $\mathbf{0 . 1}$ & $\mathbf{0 . 0 8}$ & $\mathbf{0 . 0 6}$ & $\mathbf{0 . 0 4}$ & $\mathbf{0 . 0 2}$ & Control \\
\hline Survival, \% & 9.2 & 15.0 & 76.8 & 75.0 & 76.9 & 78.0 & 76.6 & 77.7 & 80.3 & 81.0 \\
\hline
\end{tabular}

The most toxic were concentrations above $5 \mathrm{mg} /$ liter, concentrations from 00.4 to $1 \mathrm{mg}$ / liter caused a 3-6\% decrease in survival rate, a concentration of $0.02 \mathrm{mg} /$ liter practically did not reduce the percentage of survival in embryogenesis. The delay in embryonic growth in comparison with the control samples, and then the death of embryos were observed at the beginning (fouling stage) and at the end of embryonic development during the period of the circulation system activation, as a result of which toxic substances penetrated into the embryo can more effectively approach sensitive organs.

When breeding preliminaries took the long time before switching to external nutrition, it turned out that in solutions with a concentration of $0.6 \mathrm{mg} /$ liter and lower, the survival was closed to $100 \%$ (like in the control group). Higher concentrations of copper sulphate caused the death of some individuals (Table 3).

Table 3. Survival of carp larvae with holding in solutions of copper penta-sulfate of various concentrations

\begin{tabular}{|c|c|c|c|c|c|c|}
\hline $\begin{array}{c}\text { Concentration } \\
\text { CuSO4 } * \mathbf{5 H 2 O}, \mathbf{~ m g} / \text { liter }\end{array}$ & $\mathbf{3}$ & $\mathbf{2}$ & $\mathbf{1}$ & $\mathbf{0 , 8}$ & $\mathbf{0 , 0 2 - 0 , 6}$ & Control \\
\hline Survival rate, $\%$ & 40.0 & 55.0 & 80.0 & 85.0 & 100 & 100 \\
\hline
\end{tabular}

The long-term consequences of the action of copper ions in early ontogeny were revealed only in those embryos that were obtained using solutions of copper sulfate during fertilization. Among them, about $30 \%$ of individuals with various malformations were found, significantly lacked behind in growth from the rest of the group.

\section{Conclusions}


Thus, the advantage of the biological method of cooling ponds cleaning with the help of fish-meliorators can be considered proven.

\section{References}

1. V. Trifonov, O. Loyko, D. Nesteruk, S. Zhironkin, E. Strekovtsova, AIP Conf. Proceed., 1800, 050009 (2017)

2. M.I. Agienko, E.P. Bondareva, G.V. Chistyakova, O.V. Zhironkina, O.I. Kalinina, IOP Conf. Ser.: Earth Environ. Sci., 50:1, 012022

3. M. Erkayaoğlu, N. Demirel, J. Env. Man., 174, 1-6 (2016)

4. M. Cehlár, J. Janočko, Z. Šimková, T. Pavlik, E3S Web of Conf., 15, 01019 (2017)

5. M. Tyulenev, S. Zhironkin, K. Kolotov, E. Garina, Poll. Res. 35:2, 221-227 (2016)

6. M. Tyulenev, E. Garina, A. Khoreshok, O. Litvin, Y. Litvin, E. Maliukhina, IOP Conf. Ser.: Earth Environ. Sci., 50:1, 012035 (2017)

7. M. Tyulenev, Y. Lesin, E.Tyuleneva, E. Murko, E3S Web of Conf., 15, 02003 (2017)

8. M. Cehlár, P. Varga, Z. Jurkasová, M. Pašková, Acta Montanistica Slovaca, 15:2, 132138 (2011)

9. M. Prekopová, J. Janočko, Geol. Carp., 60:6, 485-494 (2009)

10. R.P. Bukata, J.H. Jerome, K.Ya. Kondratyev, D.V. Pozdnyakov, Optical Properties and Remote Sensing of Inland and Coastal Waters (Boca Raton, Florida: CRC Press, Inc.; 1995)

11. A. Collin, J.L. Hench, Rem. Sen. 4:12, 125-144 (2012)

12. M. Deidda, G. Sanna, Bathymetric extraction using WorldView-2 high resolution images. International Archives of the Photogrammetry, Remote Sensing and Spatial Information Sciences (Melbourne, Australia, Proceedings of the XXII ISPRS Congress, 2012)

13. A. Minghelli-Roman, A. Goreac, S. Mathieu, M. Spigai, P. Gouton, Int. J. Rem. Sens. 30:2, 5737-5750 (2009)

14. S. Sathyendranath, Remote sensing of ocean colour in coastal, and other opticallycomplex, waters (Dartmouth, Canada: MacNab Print, 2000)

15. R. Uma, Maheswari Int. J. Mar. Sci. 3:1, 91-97 (2013)

16. A. Akiyama, Bul. Jap. Soc. Scient. Fish. 36, 563-570 (1970)

17. N.J. Cazzaniga, Biocell. 26, 71-81 (2002)

18. C.R. Hazel, S.J. Meith, Water Proj. Branch. Lab. Rep. 16, 1-8. (1969)

19. A. Hutorowicz, J. Hutorowicz, Ecol. Ques. 9, 79-86 (2008)

20. A.L. Estebenet, P.R. Martin, Biocell. 26:1, 83-89 (2002)

21. H.R. Gordon, Applied Optics. 14:2, 413-416 (1975)

22. C.H. Bronson, Tech. Bul. 3, 2-4 (2002)

23. A. Kanno, Y. Koibuchi, M. Isobe, IEEE Geosci. Rem. Sens. Let. 8:1, 64-67 (2011)

24. C. Korschgen, W. Green, American wildcelery (Vallisneria americana): Ecological considerations for restoration (Wildlife : Fish and Wildlife Technical, 1988)

25. K. Matsukura, H. Tsumuki, Y. Izumi, T. Wada, J. Exp. Biol. 212, 246-255 (2009)

26. J.M. McKim, D.A. Benoit,. J. Fish. Res. Board Can. 28, 655-662 (1971) 
